\title{
Tourist behavior and weather
}

Understanding the role of preferences, expectations and in-situ adaptation

\section{Martin Lohmann and Anna C. Hübner}

\section{(2) OpenEdition \\ Journals}

Electronic version

URL: http://journals.openedition.org/tourisme/83

DOI: $10.4000 /$ tourisme.83

ISSN: 2492-7503

\section{Publisher}

Éditions touristiques européennes

\section{Printed version}

Date of publication: 1 December 2013

Number of pages: 44-59

ISSN: $2109-5671$

\section{Electronic reference}

Martin Lohmann and Anna C. Hübner, «Tourist behavior and weather », Mondes du Tourisme [Online], 8 | 2013, Online since 01 June 2015, connection on 10 December 2020. URL : http:// journals.openedition.org/tourisme/83; DOI : https://doi.org/10.4000/tourisme.83

\section{(ब) $(\Theta \Theta$}

Mondes du tourisme est mis à disposition selon les termes de la licence Creative Commons Attribution - Pas d'Utilisation Commerciale - Pas de Modification 4.0 International. 


\title{
Tourist behavior and weather Understanding the role of preferences, expectations and in-situ adaptation
}

\author{
MARTIN L OHMANN [m.lohmann@leuphanade] \\ Leuphana University Lüneburg, Department of \\ Business Psychology
}

\begin{abstract}
ANNA C. HÜBNER [to.annah@t-online.de] Deutsche Gesellschaft für Internationale Zusammenarbeit (Nature Conservation and Sustainable Development of Natural Resources in the Phong Nha - Ke Bang National Park Region' Project)
\end{abstract}

\begin{abstract}
This study contributes to a deeper understanding of the relationship between tourist weather preferences, perceptions, and weather-related activities. A conceptual model with respect to the interdependencies and relationships is proposed and discussed in light of the results of a pilot study conducted on the French Caribbean island of La Martinique. An explorative in-situ survey that included $n=32$ holiday tourists from 'cold' and 'warm' countries examined the core variables of the model. The results demonstrated that slight differences in climate preference existed for respondents, depending on whether they originated from a country with a cold or a warm climate, that the activity patterns seemed to be influenced by changing weather conditions only to some extent, and that the actual weather, which was marked by heavy rains in the first data collection period and by changeable weather in the second, appeared to have only limited impact on return intentions. Despite the limited possibility of a pilot study, the results facilitated an overview of the factors necessary to understand the weather-related behavior and shifts in the behavior of tourists. The core concepts include acceptance and adaptation as dynamic psychological processes that allow an individual to cope with adverse weather conditions. Thus, this study may serve as a basis for future research, especially with respect to the behavioral responses of leisure tourists to predicted climate change dynamics in holiday destinations. The conceptual model may provide a useful framework for future studies.
\end{abstract}

Résumé. Cette étude explore les relations entre perceptions du temps qu'il fait, conditions météorologiques et comportements des vacanciers. Un modèle conceptuel est proposé, à partir d'une étude réalisée à la Martinique, aux Antilles. Une enquête exploratoire, menée auprès d'un échantillon contrasté de trente-deux touristes "de loisirs" venant de pays au climat "froid" ou "chaud", a permis d'analyser les principales variables du modèle. Les résultats ont montré : qu'il y avait de légères différences dans la préférence climatique selon que les personnes enquêtées venaient d'un pays froid ou d'un pays chaud; que les conditions météorologiques n'avaient qu'un impact limité sur le type d'activités pratiquées ; que le temps qu'il faisait, qui a été marqué par des fortes pluies dans la première période d'enquête et par un temps variable dans la deuxième, n'avait qu'un impact limité sur les intentions de retour. Malgré ses moyens limités, l'étude identifie les variables et facteurs essentiels à la mise en œuvre d'un projet de recherche examinant la perception des conditions météorologiques par les touristes, d'une part, et les comportements induits, d'autre part. Les principaux concepts identifiés sont l'acceptation et l'adaptation, en tant que processus psychologiques dynamiques permettant à un individu de faire face aux mauvaises conditions météorologiques. Cette étude peut servir de base pour de futures recherches, notamment pour l'analyse des comportements des touristes face au changement climatique. Le modèle conceptuel peut fournir un cadre utile pour de futures études. 
W eather appears to influence human behavior in various ways and at different levels, ranging from a simple decision concerning what clothes to wear depending on the expectation of rain to reactions to unusual and severe weather events, such as hurricane Sandy, which occurred on the eastern coast of the US in 2012 (CBC 20 I2; Murray, Di Muro, Finn \& Popkowski Leszczyc, 20 I0). Similarly, behavior and behavior-regulating processes are related to climate factors, where climate is defined as "longterm average weather". Weather and climate have a specific and significant impact on tourism that affects the tourism industry as well as current and potential tourists. This impact may become even more pronounced with climate change.

From a demand perspective, weather and climate exert a level of influence on individual motivations for travel, a destination's attractiveness and tourist destination choice, the timing of travel for individuals, actual or planned tourist behavior at the destination, holiday satisfaction and perceived value-for-money and a consumer's return intentions (Becken, 20 I ; Becken, Wilson, \& Reisinger, 20 I0; Goh, 2012; Lohmann \& Aderhold, 2009; Lohmann \& Kaim, 1999; Mansfeld, Freundlich, \& Kutiel, 2007; Scott \& Lemieux, 2009; Scott, Hall \& Gössling 20 I2). Given the importance of weather and climate as a determining factor of tourism demand, the body of literature that explores tourist preferences, expectations, perceptions and destination experiences has steadily grown. Certain studies have employed a so-called climate index model to estimate future tourism flows and seasonality patterns on a macro-scale based on different weather conditions (Amelung, Nicholls \& Viner, 2007; Mieckowski, 1985; Morgan, Gatell, Junyent, Micaleff, Özhan \& Williams, 2000). Other studies have focused on context-specific environments, such as coastal, urban or mountainous areas, and/or the importance of natural features that include climate and weather for tourist decision-making and experiences (Rutty, 2009; Uyarra, Côté, Gill, Tinch, Viner, Watkinson, 2005).

However, there is still a lack of information concerning tourists' perceptions of weather and subsequent in situ behavior and trip planning. Seasonal changes in weather, increases in climate variability and extreme weather events either already affect tourism demand and supply systems or are projected to alter such systems in the future along with climate change processes.

These changes demand a greater understanding of the relationships that exist between tourism and weather expectations and experiences, as well as the variables that contribute to perceptions concerning comfort and holiday satisfaction. Moreover, there is a need to examine how different climatic conditions in different settings influence perception and satisfaction levels. Small tropical islands and destinations with warmer climates constitute interesting study settings. Small islands have received comparatively little attention in this research area, though tourism provides a vital source of income.
This pilot study examines weather preferences, expectations and the behavior of holiday-makers in Martinique, a small island in the Caribbean Lesser Antilles. Preliminary results of this project have been reported in a regional journal (Lohmann \& Hübner, 20I I). This study will examine the following items in detail: Climate preferences of holiday-makers with respect to a typical summer holiday; The role of weather concerning the destination choice; Actual weather perceptions; Weather-related activities; Evaluative processes.

This study does not attempt to explore all (social-psychological) decision-making factors such as perceptions, attitude, motivations or experiences in every respect. It is instead aimed at delineating a conceptual model that considers weather and climate to be drivers of tourism demand in general and, more specifically, in a small tropical island setting. The assumption is that weather constitutes an important factor for holiday-makers in a small tropical island and, therefore, that deviations from the weather preferences and expectations of tourists will result in negative perceptions of the travel experience, including value-for-money perceptions of the destination. A negative expectation-experience gap could impinge on the consumers' intentions to revisit the destination.

\section{TOURIST BEHAVIOR AND WEATHER CONDITIONS}

Literature Review. The influence of weather on human behavior is an 
interesting topic for many areas of research and application. For instance, individual social or financial behavior appears to be affected by weather variables (Cunningham, 1979; Hirshleifer and Shumway, 200I). The impact of weather on behavior has also been researched in marketing literature (e.g., Parsons, 200I).

Studies from different research areas confirm, in general, that there is a link between weather and consumer behavior. However, there are different explanatory approaches for the underlying “mechanism". Such explanations, in addition to thermoregulation, include other adaptive processes that function as a type of psychological homeostasis (e.g., mood regulation) (Parker and Tavassoli, 2000; Steenkamp and Baumgartner, 1992).

Holiday trips offer additional possibilities for consumers to look for alternative weather conditions. Vacation trips may be considered medium-term means of mood regulation. Tourists often try to find optimal conditions for physical and psychological comfort. Lohmann and Kaim (1999) presented empirical evidence with respect to German tourists and their idea of perfect weather conditions for a summer holiday. Even those tourists who visited destinations for reasons other than weather or despite poor weather, did not differ significantly in their opinion of what is considered to be "good weather" (Denstadli et al., 20। I).

Weather is the state of atmospheric elements such as temperature, precipitation, wind, sunshine, cloudiness, and visibility, whereas climate may be considered the likelihood of different weather conditions occurring. In a pioneering study, Besancenot (1989) maintained that the ideal climate for tourism should provide a basic level of comfort that includes enjoyment and safety. However, perceptions of "good" and "bad" weather are subjective and context-dependent (e.g., Jacobsen et al., 201 I; MezeHausken, 2007), as are perceptions of comfort, discomfort, pleasure, safety and other aspects related to climate that may influence destination decision-making and in-situ activity planning.

Several studies have specifically examined visitor preferences and expectations of warmer climate destinations. They demonstrated that weather is a complex concept. Tourist perception of weather considers several aspects, including not only temperature. Moreover, actual weather is evaluated with respect to the activities planned, and it is assessed differently by different target groups.

Gössling, Bredberg, Randow, Sandström \& Svensson (2006) examined the importance of climate on travel and weather perceptions of international visitors to Zanzibar. Although the island can be described as a typical "sun, sand and sea" destination, the climate did not feature in the travel decision-making process for approximately $1 / 5$ of the respondents. The preconceptions held with respect to the weather were predominantly embodied by descriptions of "warm", "humid" and "great" conditions. In the event of predicted changing weather patterns for future holidays or with increased storm, rain and humidity, temperature was perceived to have little influence on future decision-making. Similarly, Curtis, Arrigo, Long \& Covington (2009) highlighted that air temperature did not have as much influence on the sampled beach-goers in North Carolina as did wind and cloud cover.

In 2007, Mansfeld, Freundlich \& Kutiel conducted a study on tourist comfort perceptions and weather conditions in the winter resort town of Eilat in Israel. Eilat generally offers year-round warm and sunny weather. In addition to the influence of different weather conditions on satisfaction levels, as demonstrated in other studies, the study also discovered that overseas visitors were less sensitive to weather conditions than were domestic visitors. Therefore, the distance travelled also appears to influence expectations and satisfaction with weather conditions in-situ.

Rutty (2009) further investigated the "ideal" weather parameters for students coming from mid- to northern-latitude-located universities in Europe with respect to a beach or an urban holiday in the Mediterranean. Sunshine hours were rated the most important factor and were rated more important than the absence of rain, strong winds and unfavorable air temperature. No wind, a $25 \%$ cloud cover and temperatures between 27 and $32^{\circ} \mathrm{C}$ were perceived as perfect weather conditions for a beach holiday (rf. also Scott, Gössling \& de Freitas, 2007). The results also showed a lower threshold for uncomfortable air temperatures for beach holidays than for 
urban holidays $\left(7^{\circ} \mathrm{C}\right.$ warmer temperatures are acceptable on the beach) and a lower threshold for unacceptable cloud cover $(100 \%$ cloud cover for urban holidays, in contrast to a $75 \%$ cloud cover acceptance threshold for a beach holiday). Lohmann and Kaim (1999) also examined the summer holiday weather preferences of tourists planning to travel to the Mediterranean (the Balearic Islands) or to the beach destinations in northern Europe. Preferences with respect to the ideal summer holiday weather were identical for both groups of holiday-makers (plenty of sunshine, light winds, and mostly warm). While the weather expectations differed for those planning a trip to beaches in the North, the destination was nonetheless chosen for a holiday. Furthermore, the study illustrated that in-situ weather experiences had no major influence on future visitation. Respondents who expressed dissatisfaction with the weather after the actual holiday demonstrated almost as much interest in revisiting as did those who experienced no major disappointment. This observation was also made by Denstadli, Jacobsen and Lohmann (20II) in their study concerning the importance of comfort perceptions with respect to weather and climate, which affect tourists' motivation to visit northern Norway. The authors found that weather conditions did not greatly influence the visitors' overall travel plans in-situ or their future visitation intentions, even if the visitors' expectations had been positively disconfirmed. Unforeseen "good" or "bad" conditions during the holiday led to short-term adjustments such as a prolonged stay, a change of itinerary or partaking in indoor rather than outdoor activities.

With respect to tourist response to weather at the destination, de Freitas (2003) distinguished among five reaction types for individuals based on different weather conditions. Unexpected or unfavorable thermal reactions (e.g., humidity, solar radiation), aesthetic reactions (e.g., sunshine, cloud cover, daylight) and physical reactions (wind, rain, snow, ice) to climate/weather conditions can lead tourists to avoid areas with adverse conditions (e.g., from sun to shade, destination choice), change their planned activities, use structural or mechanical aids (e.g., umbrella, shelter), thermally insulate their bodies (through clothing) or adopt passive acceptance.

Conceptual Model. Prior research has shown the universal importance of climate and weather with respect to destination image and destination choice, as well as in-situ responses and adaptation. Based on the existent literature, a conceptual model is proposed ( $c f$. figure 1). The model offers a structure that examines the relationships among the weather/climate that is experienced at home, the weather that is experienced during the stay at the destination, the climate of the destination, pre-travel weather preferences, weather perceptions, and experiences at the destination, in-situ tourist behavior (planning, travel and activity), and re-visitation intention.
The white squares refer to weather and climate in physical terms, with climate at home and climate at destination offering a framework for the customer's motivation, choice and decision process and with weather during the stay functioning as a variable with which the customer must contend at the destination. Lightgrey ovals mark psychological concepts and processes. These are the important "authorities" and form the basis for reactions. Finally, darkgrey ovals identify factual behavior.

The pilot study will further examine the role of concepts such as expectations, preferences, acceptance and adaptation with respect to tourist response to actual weather during a trip.

\section{Method}

- Study Area. The 3S (sun, sand and sea) image has been a significant feature of attraction for Martinique since the development of tourism on the island during the 1950s (CMT, 20I0; Dupont, 2007). Martinique received approximately 480000 holidaymakers on the island in 2009 (with a stay longer than 24 hours). Of these arrivals, $45 \%$ visited the four major destination points located in the southern part of the island (Bruno Marques, personal communication, February 2, 20II). Martinique forms part of the overseas French territories ('DOM' = French overseas departments), which substantially influences tourism on the island (Cunningham, 2007; Gay, 2012; Momsen, 2004). The Laws of Metropolitan France largely apply to Martinique. The island is consi- 
Figure I - Conceptual model: Climate, weather, and in-situ tourist behavior

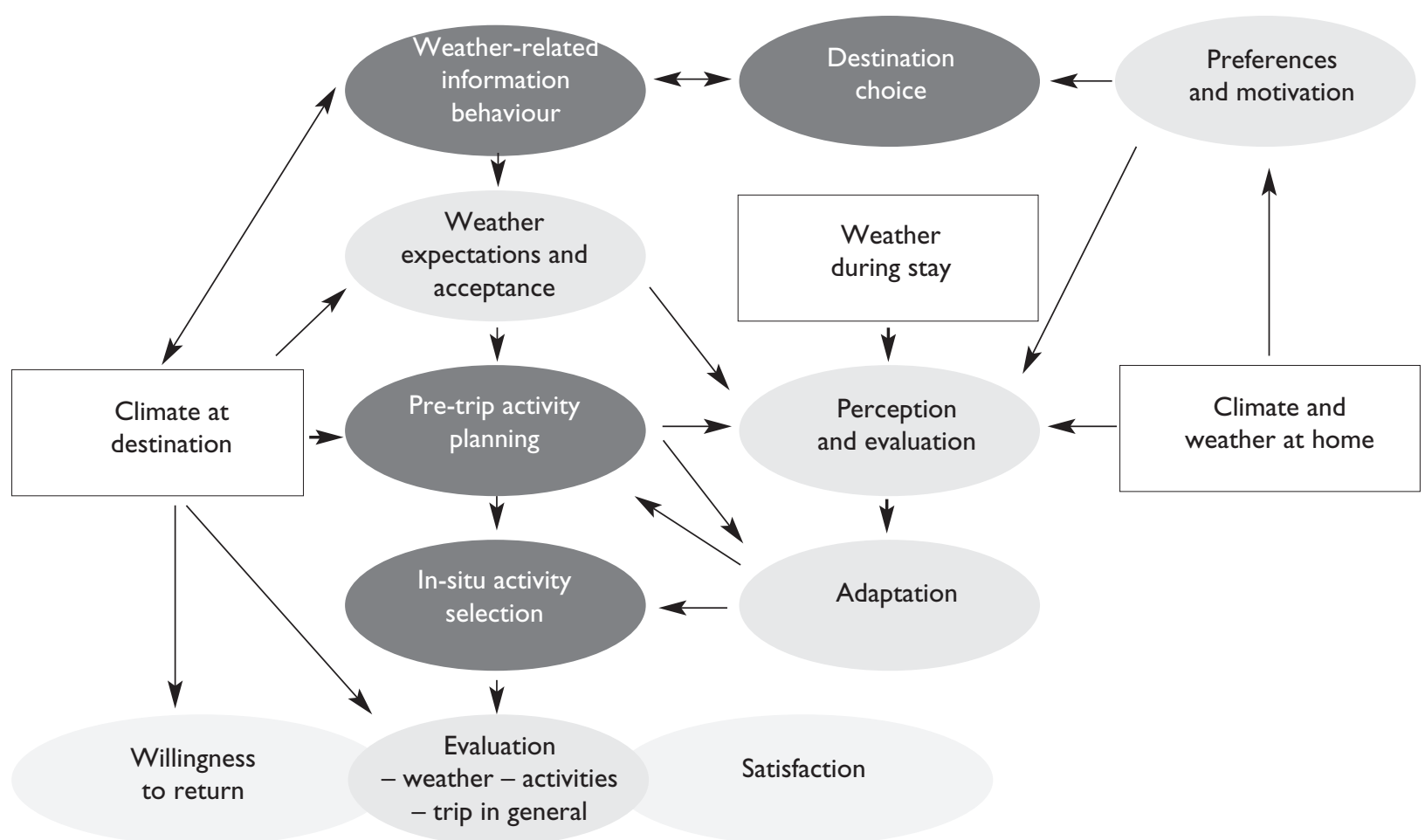

Figure 2 Average precipitation and sunshine hours from April I5 to May I7, 20 I I

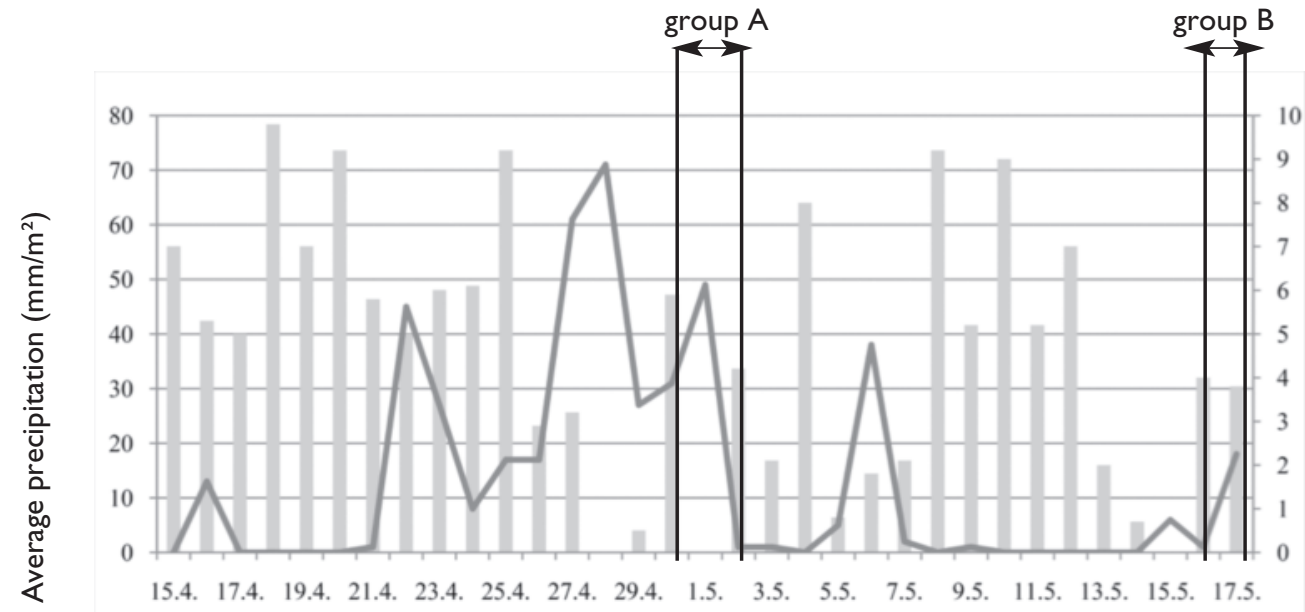

Average sunshine hours/day 
dered part of Europe's Outermost Region and is part of the European Union. Approximately $80 \%$ of the island's holiday-makers originate from mainland France (France métropolitaine). Other visitors come from the Caribbean (12.6\%), Belgium, Luxembourg, Italy, Switzerland $(2.8 \%)$, or the US $(1.4 \%)$. The average length of stay in 2009 was 13 days. Holiday-makers, on average, stayed approximately four days longer during the low season than during the high season. More than one-third of the tourists stayed with friends or relatives. Almost half of all visitors had previously visited Martinique at least once (CMT, 20I0).

Although Martinique receives the highest number of tourist arrivals in the Lesser Antilles along with Barbados (CMT, 20I0), the glamour of the island has faded. The advantages that it once held over other islands in the region (e.g., language, currency, infrastructure, direct flights from metropolitan France, safety, and medical services) are currently less effective against the rising competition of nearby tropical destinations. Its hospitality services are comparatively poor in quality and are expensive, the salaries in the public sector are exorbitant compared to those in other sectors, which has led to dissatisfaction and demotivation among tourism sector employees, and insecurity exists concerning the possibility of strikes (e.g., electricity). Investment policies, including various financial aid, tax exemptions, artificially high wages and social welfare, are becoming increasingly unstable due to a deterioration in public finances in metropolitan France (Gay, 2012). Tourism development has never been trouble-free. Developments have been marked by conflicts with respect to exclusive beach usage, land ownership, environmental issues, difficulties in socio-economic issues and global uncertainty, including the global economic crisis or volatilities in currency exchanges.

Climate change and its projected impact can add to these critical issues. Martinique's northern and southern climates vary to some degree; the northern part is more humid and tropical and has high precipitation levels of up to $5000 \mathrm{~mm} /$ year, whereas the south is much drier, with a precipitation level of $1200 \mathrm{~mm} /$ year. The average air and water temperatures are $26^{\circ} \mathrm{C}$ and $25^{\circ} \mathrm{C}$, respectively, yearround. Moreover, the climate in Martinique is characterized by a dry season, called "le carême", which lasts from approximately December to June, and by a wet season in the remaining months (called "l'hivernage"). This is also hurricane season. However, hurricanes are less frequent in Martinique than in the northern Antilles, where the water temperatures are slightly higher (INSEE, 20I0). The rainy season is the low season for the tourist industry.

- Data Collection. In order to better understand the role of weather-related preferences, expectations, perceptions, evaluations, and in-situ adaptation of holiday tourists, explorative oneon-one interviews were conducted with holiday-makers in Martinique during April and May 2011. We chose an "in-situ" approach (as opposed to conducting interviews when the tourists had returned home) to ensure that the reports reflected fresh experiences and evaluations and to facilitate interviewer and respondent interactions based on recent shared (weather) experiences (Mays and Pope, 1995; Gonzales y Gonzales and Lincoln, 2006). On selected days, potential respondents $(\mathrm{n}=52)$ were randomly approached at the international airport of Fort-de-France. Interviews were conducted only if a holiday was the prime reason for the stay on Martinique and if respondents had experienced at least a three-night stay on the island.

Two interview rounds were held within a period of a month. The first set of interviews was conducted between April 29 and May 2, 2011 (hereafter termed group A). The second set of interviews took place on May 16 and 17, 2011 (hereafter termed group B). This time period represents the end of the main holiday season for Martinique. A total of 32 interviews could be realized, 17 in group A and 15 in group B.

Because 18 of the 52 approached respondents were residents of Martinique, a response rate of $62 \%$ was considered to be reasonable. Interviews were conducted in French, English and German and lasted between 10 and 20 minutes.

The interviews were explorative and qualitative in nature. The in-situ situation did not allow for the extensive in-depth interviewing that is customary with respect to qualitative research, and we therefore attempted 
to collect data on the topics of interest using a time-saving approach. This data collection method involved a "short qualitative interview" (SQI) that was conducted on a one-to-one basis, was brief in nature but only partly standardized and allowed the respondent some flexibility with respect to answers. In other contexts, this type of methodological approach has offered useful insights (Lohmann, 2007).

The interview guide covered questions concerning weather preferences (the role of weather for the destination choice, including home weather prior to departure, the importance of weather with respect to the decision to visit Martinique and preferences for a 'typical' summer holiday), weather expectations and experiences (including perceptions of the weather and of particular weather parameters during the holiday as well as weather satisfaction), and questions that related to the activities undertaken during different weather conditions.

Qualitative, open-ended questions were combined with closed quantitative elements. Open-ended questions were used, for instance, to gather information with respect to home weather descriptions and descriptions of what "normal" weather resembles in Martinique, especially with respect to weather-related behaviors on the island. Closed quantitative elements were used for the questions that the respondents had to rate on a scale. Questions were posed on weather preferences (from "like" to "do not like"), perceptions of specific weather parameters (from "never" to "nearly all the time") and weather evaluation (from "lousy" to "excellent").

- Weather Conditions during Data Collection. The interview periods were marked by somewhat different weather conditions ( $c f$. figure 2 ). The minimum and maximum temperatures of approximately $22.5^{\circ} \mathrm{C}$ to $30^{\circ} \mathrm{C}$ correspond to normal averages for the time of the year (Météo France, $201 \mathrm{I})$. However, the precipitation levels in April were four times higher than average (135 $\mathrm{mm}$ ). In May, the precipitation levels remained high, with $191 \mathrm{~mm}$ of rain. The hours of sunshine remained below normal, with 164 hours of sunshine in April and 173 in May. During the final days of the holiday for participants in group A (late April/early May), exceptionally heavy rains and cloudy skies were evident. The final days of the holiday for participants in group $\mathrm{B}$ were also characterized by higher precipitation levels. However, for group B, there was less rain overall, and it had a shorter duration. Group B experienced slightly higher temperatures and a higher humidity level than did respondents from group A.

Figure 3 depicts a popular beach on the southern coast of Martinique experiencing rain and sunshine during the data collection period. The images illustrate the differences that may have been experienced by holidaymakers from groups $\mathrm{A}$ and $\mathrm{B}$.

- Data analysis. Consent was sought from the respondents for the recording of interviews. The interviews were then transcribed in the language in which the interview was conducted. The transcriptions follo- wed the scheme of Dresing \& Pehl $(20 \mathrm{I})$. Only the quotations used in the text were translated into English. Using the process of content analysis (cf. Mayring, 20।0), the transcripts were later scanned and categorized using the emerging themes and issues that had developed with respect to the study objectives. Subsequently, potential links among these categories were sought.

The results were analyzed separately for respondents from groups A and $B$ and, referring to the KöppenGeiger-classification (Peel, Finlayson \& McMahon, 2007), for respondents residing in a tropical country ("warm weather" country, e.g., Guadeloupe, St. Lucia) or in a country with mainly temperate or cold climates ("cold weather" country, e.g., France, Germany, Switzerland, Monaco, Argentina).

\section{Results and Discussion}

- Sample characteristics. Twelve respondents from group A were from cold countries (with three born in Martinique), and five were from tropical warm countries. Of the 15 interviewees in group B, 13 were from cold countries. The average age of participants from cold countries was 43 years, and the average stay was approximately 13 days. Warm country respondents were slightly older, with an average age of 47 years, and had a significantly shorter approximate average length of stay, i.e., four days. Female and male respondents were evenly represented in groups A and B. Overall, the sample can be characterized as predominantly 
French or French-speaking and as relatively experienced visitors to the Caribbean and to Martinique. This was the first visit to Martinique for 13 respondents; for eight of these, it was also the first visit to the Caribbean.

- Preferences and expectations. First, the respondents were asked to relate the weather conditions that were prevailing in their home country shortly before coming to Martinique. In both data collection time periods, the weather at home was considered to be predominantly "nice", "sunny" and with "pleasant temperatures".

Participants were then asked to rate their preferences of selected weather parameters for a "typical" summer holiday (cf. figure 4). "Sunny", "slightly windy" and "mostly warm" weather were favored by the majority of respondents, with "occasional showers" or "changeable weather" considered to be no more than acceptable by many. These findings are consistent with the results of previous literature (e.g., Lohmann and Kaim, 1999; Rutty 2009; Denstadli, Jacobsen \& Lohmann, 20I I). Warm country respondents similarly preferred sunny and slightly windy weather but were less unanimously accepting of warm or hot temperatures. Førland, Jacobsen, Denstadli, Lohmann, Hanssen-Bauer, Hygen and Tømmervik (2013) found a similar situation in northern Norway, where national tourist preferences closely resembled the actual climate and tourists from the southern part of Europe exhibited increased sensitivity.

The interviewees were asked specifically to describe the role of weather

\section{Figure 3 - Le Diamant beach during rain and sunshine}
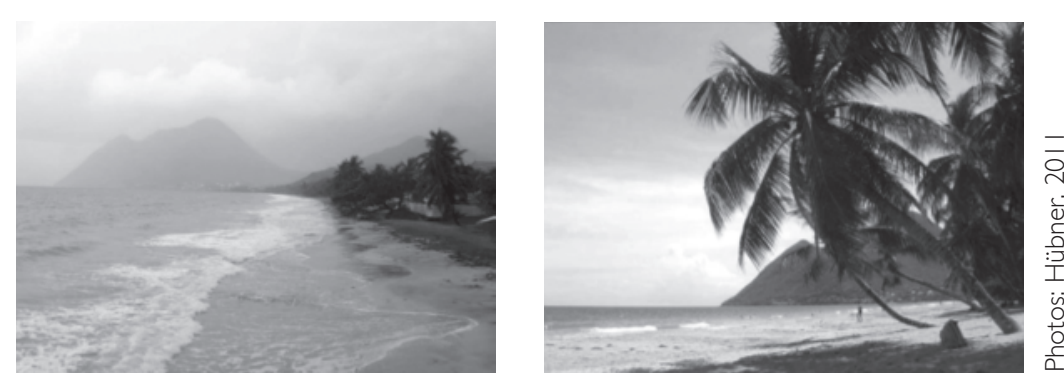

Figure 4 - Weather preferences for a "typical” summer holiday

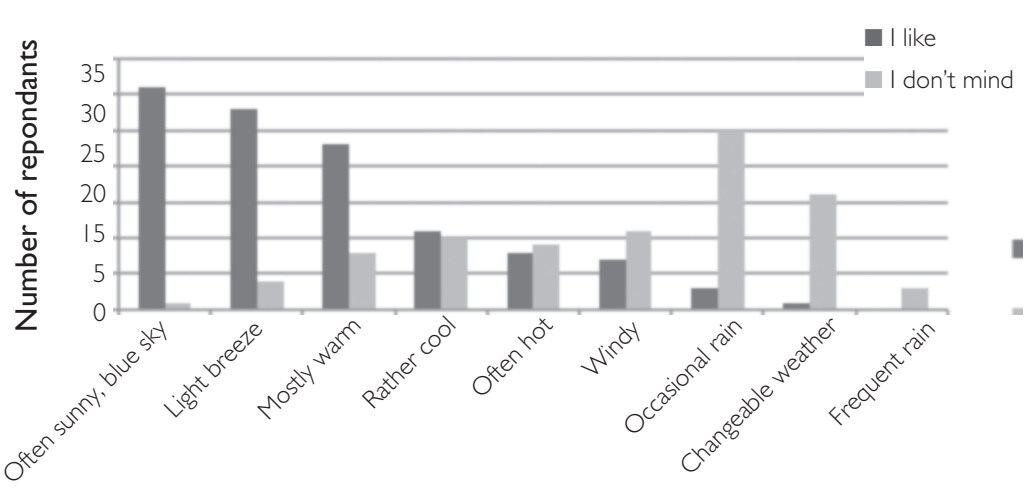

Missing cases $=$ neither like nor mind or no answer

or climate with respect to the destination choice. The answers demonstrated that weather was one important factor among many and was thus not the only reason for visiting Martinique. This result was also found by Gössling, Bredberg, Randow, Sandström and Svensson (2006) in a study that featured holiday-makers to Zanzibar. The reasons for visiting Zanzibar included safety, marine diversity, the beach, or visiting friends and relatives. In our study, the visitors' comments also suggested an implicit understanding that the weather in Martinique is considered to be "normally" and "usually", "sunny", "dry" or "good". This fin- ding is also confirmed by statements made with respect to the expected 'typical dry season' weather conditions, i.e., dry and sunny conditions with occasional, brief showers. Interviewees from warm countries also anticipated 'normally nice and sunny' weather but were more aware of the recent rainy days. This was particularly the case for respondents from Guadeloupe.

When considering their holiday destination choice, for many of the tourists, the weather in Martinique appears to be an implicit aspect that does not elicit significant concern because there is an expectation of good weather. 
Weather perceptions and evaluation. The respondents were asked to rate specific weather parameters on a scale from 1 (never experienced) to 5 (experienced nearly all the time during the holiday). With respect to the first period (group A), the weather was perceived as rainy, with an intermittently sunny and clear sky and medium temperatures. Group B respondents reported less rain, more sun, and higher temperatures and humidity.

The descriptions of the weather parameters experienced differed slightly for warm and cold country participants. Warm country respondents reported less frequent sunshine and experiencing rain "nearly all the time"; the temperatures were described as rather cool. The cool country interviewees found the temperatures higher, some even "really hot", and experienced less frequent rain. The different perceptions may be based on a different duration of the observation period because warm country respondents had substantially shorter stays ( $c f$. figure 2) and because perceptions may be based on different expectations related to the climate situation at home.

The differences were also reflected in the evaluation of the weather. Whereas respondents from group A rated the weather overall as between "mediocre" and "rather bad", group B interviewees rated the weather as "great". Warm country respondents rated the weather slightly less favorably than did cold country interviewees. These differences again may be explained by two major fac- tors. First, an extreme period of rain preceded the data collection. Second, the average length of stay for warm country respondents was much shorter, which prevented them from experiencing more typical weather conditions for mid-April.

The respondents were later questioned with respect to the relationship between their expected and experienced weather conditions, whether their expectations were met, or whether their expectations were positively or negatively disconfirmed. The results revealed that cold country respondents from groups $\mathrm{A}$ and $\mathrm{B}$ rated the weather as worse than expected $(80 \%$ in total), whereas warm country respondent evaluations were more balanced, with half of them believing that their weather expectations were met.

Interviewees originating from cold countries made certain interesting comments concerning the weather that they had experienced. For some respondents, the amount of rain was "unusual" and "abnormal". Others appeared to have anticipated the rain because they had been informed of the weather or because they may have experienced similar weather conditions during previous travels to Martinique and/or to the region (cf. figure 5). Overall, three categories of remarks were derived from interviewees: negative irritation with respect to the weather (the experience did negatively match expectations) from cold country respondents and neutral acceptance (the experience came close to what was expected) from both cold and warm country respondents.
The respondents made rationalizations that were determined by previous travel experiences of other information sources (friends or relatives, media, home weather).

The results indicate that acceptance is based on information. This finding is consistent with the 'Expectancy Disconfirmation Model' used in satisfaction research (e.g., Walker, 1995). Tourists who are informed of actual weather conditions or are familiar with the potential volatility of regional weather have realistic expectations and therefore accept adverse weather conditions more easily.

- In-situ activities and weather conditions. To explore the potential relationship between the weather conditions that an individual experiences and the resulting activities, the participants were questioned with respect to the activities in which they engaged. The respondents named a great variety of activities, including going to the beach, diving/snorkeling, swimming, sailing, hiking/walking, and visiting villages, museums and distilleries. Warm country respondents' activities concentrated on hiking or walking, visiting friends and relatives and going to the beach.

When questioned more specifically with respect to any plans or activities that had to be altered because of unexpected weather conditions, cold country respondents from group A stated at least one planned activity change. Among these changes were the cancellation of hiking or walking or sailing trips ("We were hiking but had to return because of rain.") or other activities ("With this weather, 


\section{Figure 5 - Expectations and experience with respect to weather conditions}

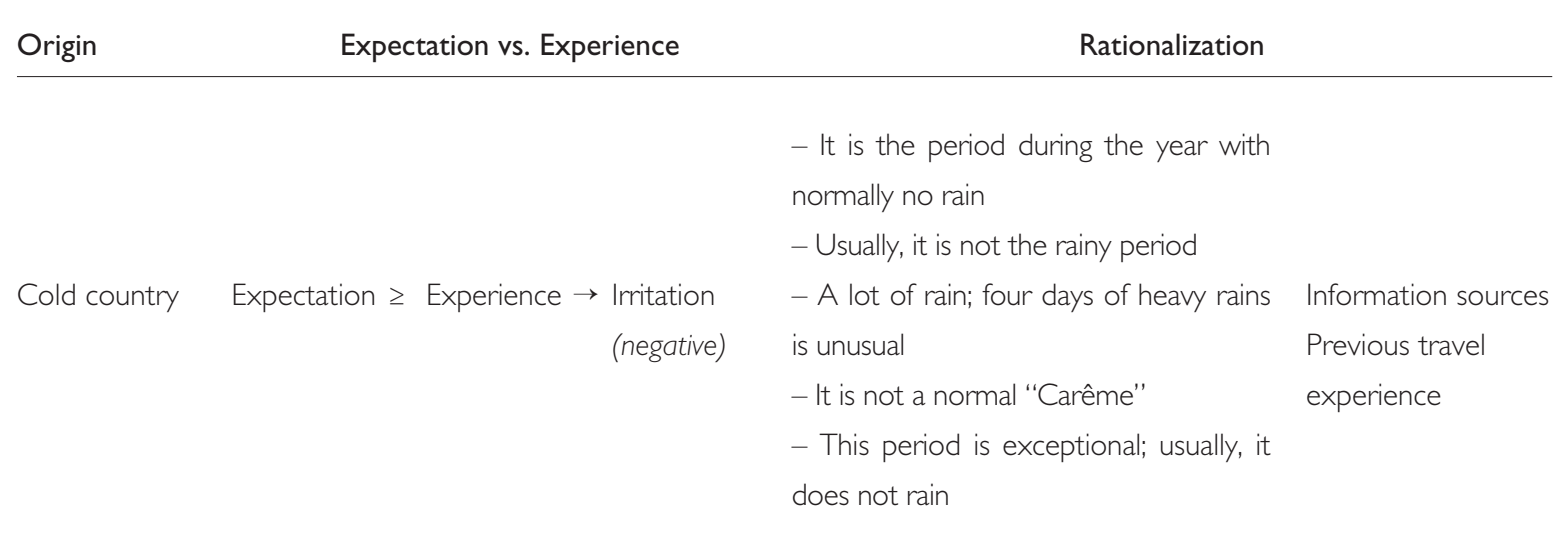

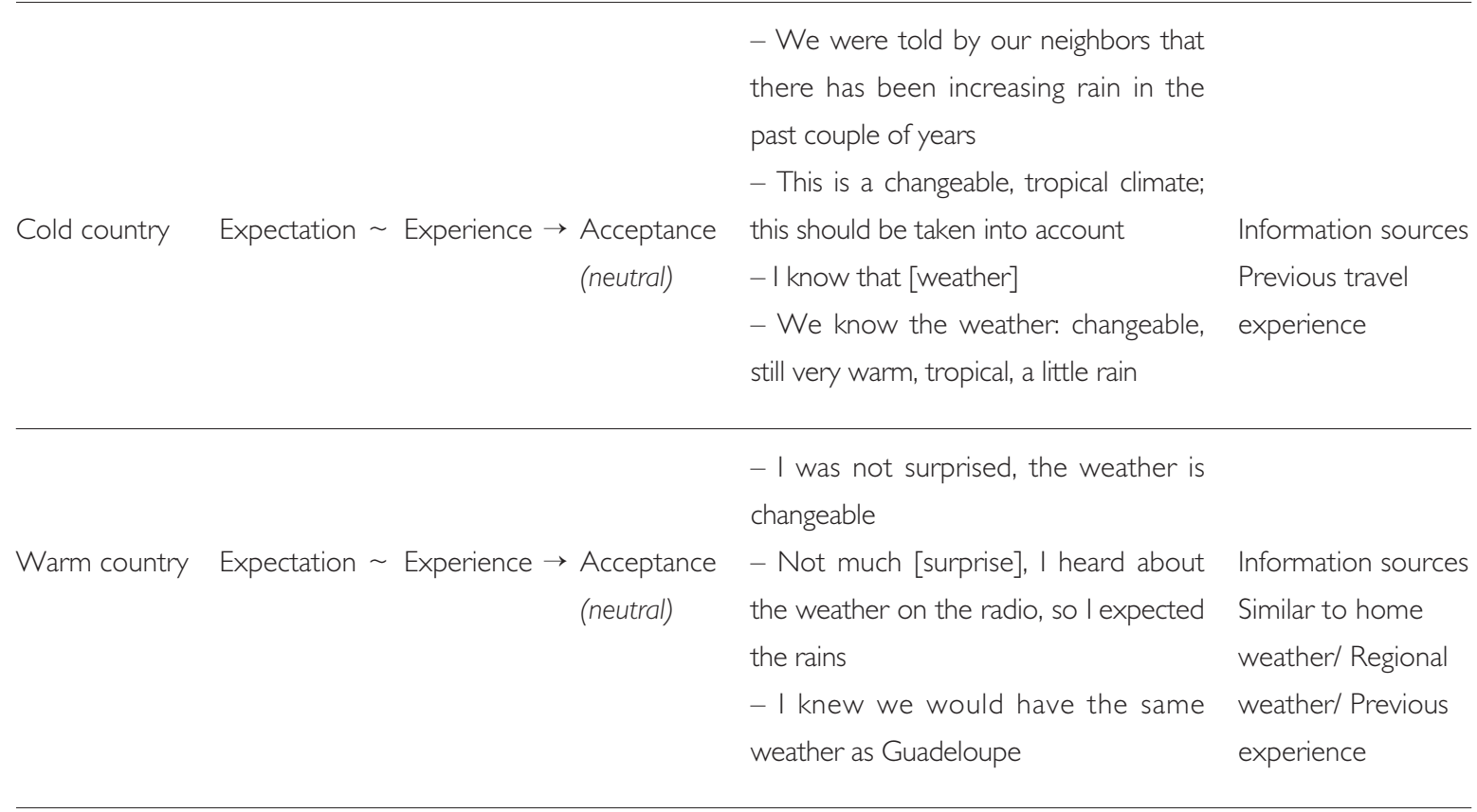

we weren't able to do what we had intended to do."), a change in the mode of transport, or changes from an outdoor to an indoor activity, such as visiting a museum. The latter was even considered an opportunity ("We benefitted from visiting the museum."). These adaptive behaviors also confirmed de Freitas' (2003) findings, who outlined that the adoption of passive weather acceptance includes an avoidance of areas with adverse weather conditions. However, a number of interviewees stated that the weather conditions had minimal influence on their activities ("Even if it rains, one can go diving"; "Not at all [any changes], because weather conditions change rapidly."; "It doesn't matter a lot because it [the rain] usually doesn't last for long.").

Group B participants appeared more likely to consider going to the beach during rainy or cloudy weather conditions, which may have been due to the less intense and briefer periods of rain compared to the first period of data collection. Overall, fewer changes were reported by group $\mathrm{B}$ participants. Moreover, respondents from warm countries generally seemed to have less fixed ideas with respect to planned activities and, therefore, gave much fewer details concerning any changes.

To obtain further insight into the 
potential relationships between weather conditions and actual behavior, interviewees were questioned with respect to the weather and the activities undertaken during the day prior to the interview. Although the weather was generally described as rainy and cloudy, respondents from cold countries nevertheless engaged in various activities; these included walking, touring the island, or snorkeling. Respondents who participated in snorkeling highlighted that this activity depends more on high waves rather than rain, which was also mentioned by a few participants who participated in swimming in the sea.

Despite little daytime change in weather, it was noted that interviewees had undertaken most outdoor activities in the afternoon, and the assumption was made that mornings were spent indoors/at the accommodation, whereas the respondents were more inclined to engage in outdoor activities in the afternoon, irrespective of weather conditions. This could be an adaptive strategy, i.e., postponing activities to the afternoon in the hope of better weather and spending the morning in the hotel engaged in "light activities", such as playing board games or going to the swimming pool.

An activity that is typical for the final day spent at a destination is packing to prepare for the return trip, which has to be done regardless of weather conditions. Therefore, spending time at the accommodation is inevitable to some extent.

The overall reactions seemed to be twofold: certain interviewees seemed less than impressed by the wea- ther and expressed a desire to maximize holiday satisfaction. In this respect, it also appeared that the completed activities had been planned before traveling to Martinique. The other group of respondents, which mostly consisted of repeat visitors, seemed less likely to venture out during "rainy" weather and adopted a more flexible and accepting attitude towards staying indoors. Plans and activities were more often cancelled or postponed. One participant emphasized that he would determine the daily local weather conditions and then plan activities for the following day accordingly. Warm country respondents overall engaged less in outdoor activities during "bad" weather conditions than did their cold country counterparts and were less concerned with spending a day indoors.

-Willingness to return. Holidaymakers were asked whether they would revisit Martinique in the near future to discover any potential influence of the experienced weather on return intentions. The respondents, surprisingly, seemed little affected by the prevailing weather and largely said that a return visit was likely ( 28 of the 31 interviewees indicated a probable or definite intention to revisit). Certain cold country participants commented that an earlier time of the year would be considered for a repeat visit. Others noted, again, that the experienced weather had been "exceptional" and that no other time of the year would be chosen for a return visit. Moreover, factors other than the weather were considered to be more important at times. Another aspect mentioned in this context was that the weather insecurities were easier to accept with a lower price level during shoulder seasons. Thus, the acceptability of weather conditions seems to be "negotiable".

Little or no influence on the willingness to return, despite negatively confirmed weather experiences at the destination, would also support the observations made by Lohmann and Kaim (1999) and Denstadli, Jacobsen \& Lohmann (20II). Therefore, the following hypothesis is suggested: unless weather experiences are repeatedly negatively disconfirmed, negative perceptions of weather at a holiday destination do not influence the future willingness to visit.

In addition, it was noted that respondents began to de-emphasize the importance of weather on the holiday experience at the end of the interview. Instead, the friendliness of people and the abundance of activities were highlighted, which compensated for the 'unfortunate' weather ("It has been pleasant enough despite the rain"; "We don't mind the rain; it is cheaper to stay here during the low season. Yes, I would have liked to take a swim more often, but that's life, the fish are there nevertheless"; "We would have been more disappointed if we hadn't checked the weather forecast beforehand").

- Limitations. Given the limited number of interviews conducted and the differences to average weather on the island, the results cannot be generalized (e.g., to the usual weather-related behavior of tourists on 
Figure 6 - Tourist in-situ weather evaluations and weather-related behavior in relation to pre-and post-trip planning

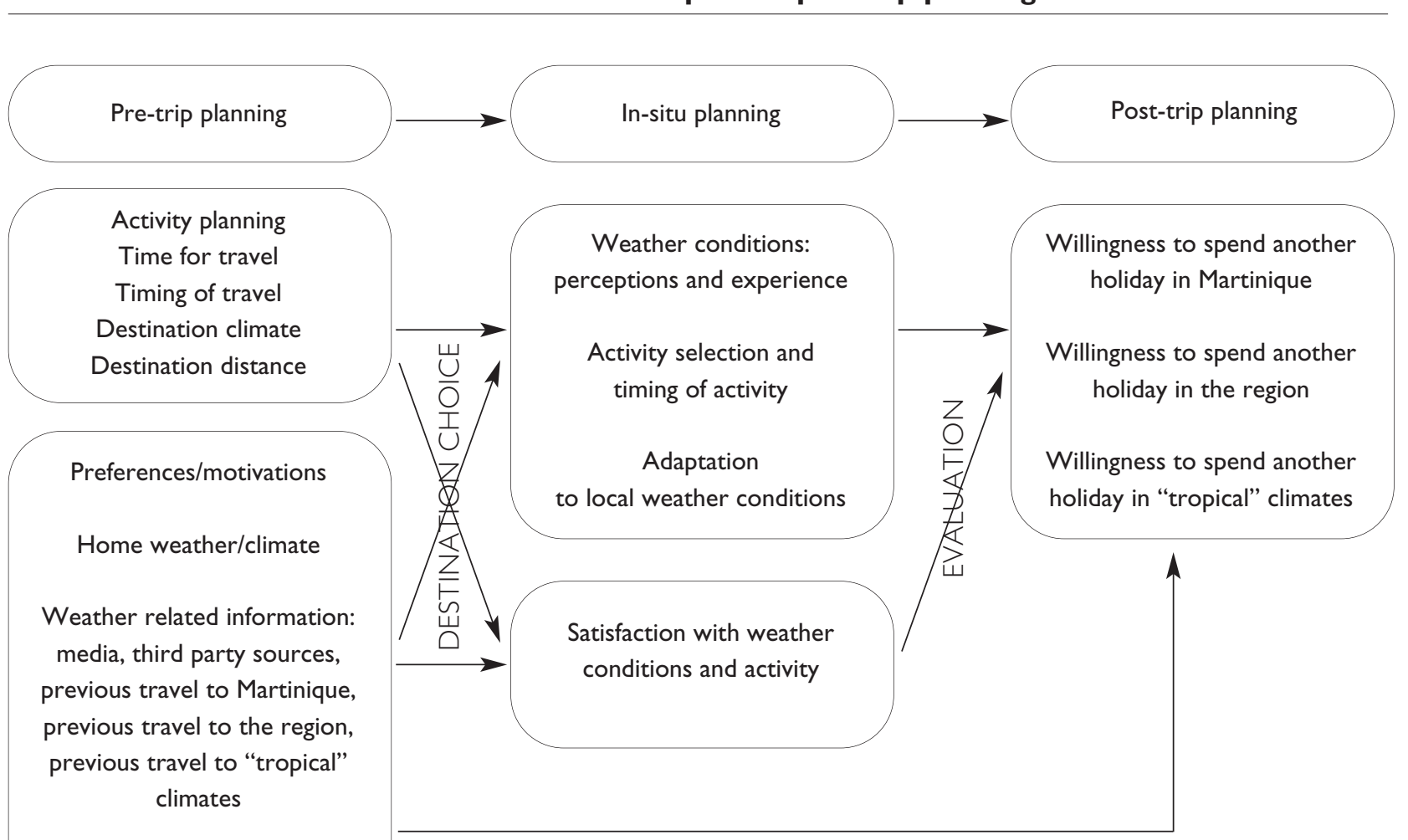

Other socio-psychological factors

Martinique). The small sample size was not considered a major impediment to the identification and exploration of different factors of the conceptual model or to the concurrent discussion of the quantitative and qualitative data because the study emphasized gaining a better and more detailed/in-depth understanding of the variables that determine weatherrelated behavior and future travel intentions. With respect to weather preferences, the subjects showed average (or "normal") attitudes that were consistent with prior research (Lohmann and Kaim, 1999; Rutty 2009; Denstadli, Jacobsen \& Lohmann, 20 I I).

The dependency of the results may be an issue, as is the case with all insitu studies, e.g., the actual weather conditions may have an influence on expressed general preferences $(c f$. Gössling, Scott, Hall, Céron \& Dubois, 2013). It should also be noted, therefore, that the timing of and the weather during data collection may have influenced the stated importance of "sunny" weather. With respect to the explorative objectives of this study and the lack of a desire for absolute thresholds, this factor may be of minor importance.

The categorization of participants into "warm" and "cold" source country respondents did not address solely climate variables. For some respon- dents who were categorized as 'warm country' respondents, holiday-making was not the prime reason for visiting the island, whereas certain "cold country" participants cited a relaxing time to recuperate as the main reason. Different travel motivations may have an impact on weather evaluations and the weather-related choice of activities.

\section{CONCLUSION}

Recent studies on the role of weather parameters for decision-making largely concentrate on pre-trip destination choice and on the econometric models used to project tourism flows in the context of a changing 
climate. Less attention has been given to tourists' perceptions and experiences of weather and activities undertaken in-situ. This pilot study examined weather perceptions and tourist behavior on a small tropical island, specifically, Martinique. The location of this study has a number of important implications: (1) it is a heliocentric destination that largely attracts visitors through its climate; (2) it is set in a region that is most vulnerable to projected changes in climate; accordingly, the potential relationships between weather and activities may provide some important insights into tourist decision-making; (3) there are limited opportunities to 'escape' the actual weather conditions or change the daily itinerary (unlike Becken et al., 20 I0; Denstadli et al., 20I I); and (4) a large portion of Martinique holidaymakers are repeat visitors stemming from one single source market. The benefit of an in-situ study is to have access to actual tourists' perceptions and recent experiences.

The reports of our respondents clarified that typical weather (climate) is an important issue when planning a holiday in the Caribbean but that it is not the only issue. When considering the destination, weather variables seem to be - at least partly - implicit. Weather variables only become an explicit issue when the weather conditions at the destination differ from the expectations.

A major purpose of this study was to explore the potential variables that need to be considered for a reliable quantitative or qualitative study conducted in a similar context, i.e., with tourists originating from both warm and cold climate source markets. The impact of (bad) weather on in-situ tourist behavior may depend on a large set of factors, including different weather parameters such as temperature, precipitation, and wind but additionally, the climate at home, the duration of stay, the type of activities available, the availability of alternative activities, and mobility. Personality factors may also be significant, but this area was not covered in our study.

This study also demonstrated that holiday-makers who pursue activities that are less dependent on sunny weather conditions, such as diving or snorkeling, were less affected by the prevailing weather conditions than were the holiday-makers whose main focal point for activity was the beach. Similarly, participants arriving from cold climate countries seemed more determined to undertake their planned outdoor activities than their warm climate counterparts, which may also be connected to the long distances traveled to an exotic destination, e.g., in the case of Europeans. Similarly, first-time visitors appeared to be more determined to undertake specific activities that were planned prior to travel than were repeat visitors.

However, even when the adverse weather conditions were contrary to expectations, dissatisfaction was not necessarily the result, which is not consistent with certain satisfaction theories (cf. Alegre \& Garau, 20l0). Here, cognitive dissonance (Festinger, 1957) could be a factor. Travelers originating from cold countries can be expected to experience a level of cognitive dissonance. This dissonance would be the result of high costs (distance traveled, time and money spent) and reduced holiday quality in terms of weather. The theory assumes that individuals tend to reduce dissonance by adapting evaluations or attitudes. In the case of this study, reducing dissonance would lead to better perceptions and evaluations of the holiday stay in general. The results provided some evidence in this direction. It is unlikely that weather perceptions are subject to such a process; however, without an internal cognitive dissonance reducing mechanism, the evaluations of weather might have been worse.

Generally, tourists exhibit a level of "resilience", "adaptive competences" and flexibility with respect to weather. We argue that "adaptation" and "adaptability" are key concepts in understanding the multifaceted behavior of tourists under unfavorable conditions ( $c f$. figure 1). Certain respondents exhibit remarkable adaptive capacity in coping with the weather. Strategies used by interviewees included the following: - Adhering to plans, even when the weather was not optimal for the activity;

- Re-evaluation of circumstances and a temporal acceptance shift with respect to the weather conditions ( "it is not that bad, actually"), most likely based on the perception that you simply cannot control the weather; - Changing plans with respect to activities, thus leading to a behavioral shift (visiting a cultural heritage attrac- 
tion instead of a day on the beach).

With few exceptions (e.g., Allex et al., 20 I I, for city tourists in Vienna), adaptive processes among tourists with respect to weather or climate conditions have not been the focus of tourism research. Adaptation can occur either as an immediate reaction to experienced weather changes or as an indirect reaction to upcoming weather events. The choice of adaptive behavior seems to depend on visitor characteristics (e.g., the long-haul holiday traveler to a once-in-a-lifetime destination is less flexible with activities). More broadly, the climaterelated destination choice can be considered an adaptation process or active mood regulation activity. Therefore, in the research area of tourism and climate (change), the focus should include not only adaptation strategies for tourism stakeholders (Dubois \& Céron, 2006, p. 404) and the adaptive capacities of consumers.

Overall, the return intentions appear to be less influenced by negatively disconfirmed weather conditions than could be assumed. General beliefs with respect to a "normal" Martinique climate appeared to have a greater impact on future visitation intention than negatively disconfirmed weather experiences during the holiday.

Pre-trip information behavior and the results with respect to weather may cause shifts in the process because this information affects weather expectations. In our sample, certain respondents during the second period of data collection (group B) seemed to anticipate "bad" weather conditions because they had used information sources at home that warned them of unusual weather predicted for the second half of April, i.e., the days directly preceding their stay. This information had lowered their weather expectations, particularly with respect to sunshine. However, warm climate respondents were overall less dependent on weather conditions, and these conditions appeared to be relatively insignificant in their destination choice.

- Conceptual Model Revisited. Considering the different factors that are related to the home environment, the situation at the destination and tourists' actual behavior planning and behavior, we argue that different psychological concepts can be used to explore the link among these factors. Given the conceptual model presented in figure 1, figure 6 appears to draw a more detailed but still preliminary picture that depicts the relationships and links that have been indentified in this pilot study. This conceptual model is a type of "conceptual scheme" (Pearce, 2005). The model expands beyond mere statements of the observed world, but it is not a fully functioning theory. It may, however, be helpful in organizing empirical information and in structuring further research.

The actual weather at a destination during a holiday does not directly correspond to activities or changes in activity, but it is subject to perception and evaluation processes. These processes are linked to weather and climate at home, weather preferences and motivation, and weather expectations and acceptance. The cognitive and emotional processes involved may be implicit or explicit. The data collected support the assumption that these processes become more explicit with unexpected developments (unusual weather), especially when the weather is adverse to the anticipated holiday experiences and activities. Additionally, the acceptability of weather conditions seems to be 'negotiable': when prices are low (during the low season), bad weather is easier to accept. Of course, many other destination- and home-related factors also influence tourist wants and behaviors, including personal abilities and motivation (cf. Lohmann, 2009). These factors are not depicted in the conceptual model.

- Future Research. This pilot study, given its limitations, provides an overview of the factors that are necessary to understand tourists' weather-related behavior and behavior shifts, and weather related psychological processes. The study may serve as a basis for future research, especially with respect to the behavioral responses of leisure tourists to projected climate change dynamics in holiday destinations, and the conceptual model may provide a useful framework. Emphasis should be given to the exploration of the role of tourist adaptation and adaptive capacity.

\footnotetext{
Acknowledgement: The authors thank Bruno Marques, CMT, Fort-de-France (Martinique, France) for his valuable information about the situation of tourism in Martinique.
} 


\section{BiBLIOGRAPHY}

Joquin AlEgRE \& Jaume GARAU, "Tourist Satisfaction and Dissatisfaction". Annals of Tourism Research, vol. 37, n I, 2010. Brigitte AlleX, Christiane Brandenburg, Ursula LieBL, Thomas Gerersdorfer \& Christina CzACHS, "Hot town, summer in the city", Endbericht von Start-Clim20 I O.F, 201 I.

Bas Amelung, Sarah Nicholls \& David Viner, “Implications of global climate change for tourism flows and seasonality", Journal of Travel Research, vol. 45, n³, 2007.

Susanne BECKEN, "The Importance of Climate and Weather for Tourism", Land Environment and People (LEaP) background paper, Lincoln University, 2010.

Susanne BECKEN, Jude WILSON \& Andy REISINGER, "Weather, Climate and Tourism: A New Zealand Perspective", Land Environment and People (LEaP) Research Report $n^{\circ}$ 20, Lincoln University, 2010.

Jean-Pierre Besancenot, Climat et Tourisme, "Géographie", Masson, 1989.

CBC, “Eastern U.S. braces for Hurricane Sandy", CBC news [http:// wuw.cbc.ca/news/.../eastern-u-s-braces-for-hurricane]. CMT, Bilan Grand public 2009, Comité martiniquais du tourisme, 2010.

Catriona CunNingham, "Reclaiming 'paradise lost' in the writings of Patrick Chamoiseau \& Edouard Glissant", French Cultural Studies, vol. $18, n^{\circ} 3,2007$.

Michael R. CunNINGHAM, "Weather, mood, and helping behavior: Quasi experiments with the sunshine Samaritan", Journal of Personality and Social Psychology, vol. 37, $\mathrm{n}^{\circ} \mathrm{II}, 1979$

Scott CURTIS, Jennifer ARRIgo, Patrick LoNg \& Ryan Covington, Climate, Weather and Tourism: Bridging Science and Practice, Center for Sustainable Tourism, East Carolina University, 2009.

Jon Martin Denstadl, Jens Kr. Steen Jacobsen \& Martin

LOHMANN, "Tourist perceptions of summer weather in Scandinavia", Annals of Tourism Research, vol. 38, n³, 2011.

Thorsten Dresing \& Thorsten PeHL, Praxisbuch Transkription. Regelsysteme, Software und praktisch Anleitungen für qualitative Forscherlnnen, 20 I I [http://mww.audiotranskription.de/PraxisbuchTranskription.pdf].
Ghislain DuBOIS \& Jean-Paul CÉRON, "Tourism and Climate Change: proposals for a research agenda", Journal of Sustainable Tourism, vol. $14, n^{\circ} 4,2006$

LouIs Dupont, “Modélisation de l'activité touristique. Application à la Guadeloupe et à la Martinique", Espaces tourisme et loisirs, n² 248 , 2007.

Leon Festinger, A theory of cognitive dissonance, Row Peterson, 1957.

Eirik J Førland, Jens Kr. Steen Jacobsen, Jon Martin Denstadl, Martin LoHMANN, Inger HansSen-BAUER, Hans Olav Hygen \& HANSTøMMERVIK, "Cool weather tourism under global warming, comparing Arctic summer tourists' weather preferences with regional climate statistics and Projections", Tourism Management, vol. 36, 2013.

Chris DE FreITAS, "Tourism climatology: evaluating environmental information for decision making and business planning in the recreation and tourism sector", International Journal of Biometeorology, vol. $48, n^{\circ}$ I, 2003.

JEAN-Christophe Gay, "Why is tourism doing poorly in overseas France?", Annals of Tourism Research, vol. 39, n 3, 2012. Carey GoH, "Exploring impact of climate on tourism demand", Annals of Tourism Research, vol. 39, n० 4, 2012.

Stefan Gössling, Daniel SCOTT, Michael Hall, Jean-Paul CÉRON \&

Ghislain DuBols, "Consumer behavior and demand response of tourists to climate change", Annals of Tourism Research, vol. 39, n I, 2013.

Stefan Gössling, Magnus Bredberg, Anna Randow, Elin SANDSTRÖM \& Patrick SVEnSSON, "Tourist Perceptions of Climate Change: a study of international tourists in Zanzibar", Current Issues in Tourism, vol. 9, $\mathrm{n}^{\circ}$ 4, 2006.

\section{Elsa M. GonZÁlez y GonZÁlez \& Yvonna S. LiNCOLN,}

“Decolonizing Qualitative Research: Non-traditional Reporting Forms in the Academy", Forum Qualitative Sozialforschung / Forum: Qualitative Social Research, vol. 7, n I, 2006.

David HIRSHLEIFER \& Tyler SHumWAY, "Good day sunshine: stock returns and the weather", Journal of Finance, vol. 58, n³, 2001. INSEE, Tableaux économiques régionaux de la Martinique 2009-2010, 2010 [http://www.insee.fr/fr/insee_regions/martinique/themes/ ter/ter2010/ter2010_ma.pdf. 2010]. 
Jeen Kr. Steen Jacobsen, Jon Martin Denstadl, Martin LohmanN \&

Eirik J. FøRLAND, "Tourist weather preferences in Europe's Arctic", Climate Research, vol. 50, 201 I.

Martin LoHMANN, "Tourist Information Behavior 'en route"', paper presented to the 5th Symposium of the International Society of Culture, Tourism, and Hospitality Research, June 5, 2007.

Martin LoHMANN, "Coastal Tourism in Germany - Changing Demand Patterns and New Challenges", in Ross DowLING \& Christoph PFORR (eds.), Coastal Tourism Development - Planning and Management Issues, Cognizant, 2009.

Martin LOHMANN \& Peter ADERHOLD, Urlaubsreisetrends 2020: Die RA Trendstudie, FUR (Forschungsgemeinschaft Urlaub und Reisen), 2009. Martin LOHMANN \& Anna C. HÜBNER, "Tourists' weather perceptions and weather related behavior. A qualitative pilot study with holiday tourists to Martinique", Études caribéennes, n 19, 201 1.

Martin LOHMANN \& Eike KAIM, "Weather and holiday destination preferences: image, attitude and experience", Tourism Review, vol. 54, $n^{\circ} 2,1999$.

Yoel MANSFELD, Ariel FreUNDLICH \& Haim KUTIEL, "The relationship between weather conditions and tourists' perception of comfort: the case of the winter sun resort of Eilat", in Bas AMELUNG, Krzysztof BlazejczYK \& Andreas MatZARakis (eds.), Climate Change and Tourism, Assessment and Copying Strategies, 2007

[http://www.urbanclimate.net/matzarakis/papers/Book_Nato.pdf]. Philipp MAYRING, Qualitative Inhaltsanalyse. Grundlagen und Technike, Beltz Verlag, 2010.

Nicholas MAYS \& Catherine POPE, "Rigour and qualitative research", BMJ , vol. 31।, 1995.

Météo France Antilles-Guyane, Bulletins climatiques mensuels, 20 I |

[http://www.meteo.gp/Climat/index.php].

Elisabeth MeZE-HAuSKEN, "Grasping climate perceptions as an issue of measuring climate impacts on society", Intemational Journal of Biometeorology, vol. 52, n I, 2007.

Zbigniew MIECZKOWSKI, "The Tourism climate index: a method of evaluating world climates for tourism", Canadian Geographer, vol. 29, $n^{\circ} 3,1985$.

Janet MOMSEN, "Post-colonial markets: new geographical spaces for tourism", in David Timothy DuvAL (dir.), Tourism in the Caribbean: Trends, Development, Prospects, Routledge, 2004.
Robert Morgan, Enrique Gatell, Roca Junyent, Anton Micallef, Erdal ÖZHAN \& Allan T. WILLIAMS, "An Improved User-Based Beach climate index", Joumal of Coastal Conservation, vol. 6, n I, 2000.

Kyle B. Murray, Fabrizio DI Muro, Adam FInN \& Peter PoPKOWSKI LESZCZYC, "The Effect of Weather on Consumer Spending", Joumal of Retailing and Consumer Services, vol. 17, $\mathrm{n}^{\circ}$ 6, 2010.

Philip M. PARKER \& Nader T. TAVASSOL, "Homeostasis and Consumer Behavior across Cultures", Intemational Journal of Research in Marketing, $n^{\circ}$ 17, 2000.

Andrew G. Parsons, "The Association between daily weather and daily shopping patterns", Australasian Marketing Joumal, vol. 9, n², 2001.

Philip L. PeARCE, Tourist Behaviour. Themes and Conceptual Schemes, Channel View, 2005

\section{Murray PeEL, Bryan L. FInLAYSON \& Thomas A. McMahon,}

"Updated World Map of the Köppen-Geiger climate classification", Hydrology and Earth Systems Sciences, vol. 4, 2007.

Michelle Kimberley RUTTY, Will the Mediterranean become 'too hot' for tourists? A reassessment, Master thesis submitted to the University of Waterloo, Canada, 2009.

Daniel ScotT, Stephen Gössling \& Chris DE FreITAS, "Climate preferences for tourism: an exploratory tri-nation comparison",

Developments in Tourism Climatology, 2007.

Daniel SCOTT \& Christopher LemieuX, "Weather and Climate Information for Tourism", Commissioned White Paper for the World Climate Conference 3. WMO and UNWTO, 2009.

Daniel ScotT, Colin Michael Hall \& Stephan GössLING, Tourism and Climate Change: impacts, adaptation and mitigation, Routledge, 2012. Jan Benedikt SteenkAMP \& Hans BaumgarTner, "The Role of optimum stimulation level in exploratory consumer behavior", Joumal of Consumer Research, vol. 19, n 3, 1992.

Maria C. UYARRA, Isabelle M. CÔtÉ, Jennifer A. GILL, Rob. R. TINCH, David VINER \& Andrew R. WATKINSON, "Island specific preferences of tourists for environmental features: implications of climate change for tourism-dependent states", Environmental Conservation, vol. 32 $n^{\circ}$ I, 2005

James L. WALKER, "Service Encounter Satisfaction", Journal of Services Marketing, vol. 9, n I, 1995. 